\title{
Microstructure and mechanical properties of aluminum cast alloy $\mathrm{A} 356$ reinforced with dual-size $\mathrm{B}_{4} \mathrm{C}$ particles
}

\author{
J. R. Chandrashekar \\ Department of mechanical Engineering, Government Polytechnic, KGF, Kolar, Karnataka, India. \\ chandrujramanna@gmail.com
}

M. H. Annaiah

Department of Mechanical Engineering, Sapthagiri College of Engineering, Bangalore, Karnataka, India drannaiabmb@gmail.com

\section{R. Chandrashekar}

Department of Mechanical Engineering, Sambhram Institute of Technology, Bangalore, Karnataka, India rajchandras@gmail.com

\begin{abstract}
The paper details the studies carried out on a dual-size particulate composite prepared by stir casting using A 356 aluminum alloy and $\mathrm{B}_{4} \mathrm{C}$ powders. Three composite compositions, viz., A356 plus $2 \% \mathrm{~B}_{4} \mathrm{C}(44 \mu \mathrm{m}$ size and $105 \mu \mathrm{m}$ size in $1: 1$ ratio), $4 \% \mathrm{~B}_{4} \mathrm{C}$ (3:1 ratio), and $6 \% \mathrm{~B}_{4} \mathrm{C}$ (1:3 ratio) were cast in finger molds, from which test specimens were prepared for hardness and tensile tests as well as for metallography. Vickers hardness tests, tensile tests and microstructure analysis using an optical microscope were conducted. The results obtained indicated that the $\mathrm{B}_{4} \mathrm{C}$ particles were evenly distributed in the alloy matrix. EDS also revealed the presence of $\mathrm{B}_{4} \mathrm{C}$ in all the three composites. In general, the hardness and tensile strengths increased with increase in concentration $\mathrm{B}_{4} \mathrm{C}$ powders. While the increase in hardness was increases less than 15\%, there was significant increase (more than $35 \%$ ) in tensile strength. However, the ductility represented by $\%$ elongation, which was already very low in A 356 cast alloy $(24.2 \%$,), further decreased in composites. Tensile fractography results shows inter crystalline fracture where the breakage in the $\mathrm{B}_{4} \mathrm{C}$ particle instead of deboning were observed.
\end{abstract}

KeYwORDs. A356 Aluminum Alloy; Dual-size composites; Microstructure; Mechanical tests; Fractrography analysis.

\section{OPEN $\odot$ ACCESS}

Citation: Chandrashekar, J. R., Annaiah, M. H., Chandrashekar, R., Microstructure and mechanical properties of aluminum cast alloy A356 reinforced with dual-size B4C particles, Frattura ed Integrità Strutturale, 57 (2021) 127-137.

Received: 17.05 .2021

Accepted: 05.06 .2021

Published: 01.07.2021

Copyright: (C) 2021 This is an open access article under the terms of the CC-BY 4.0, which permits unrestricted use, distribution, and reproduction in any medium, provided the original author and source are credited.

\section{INTRODUCTION}

luminum alloys find application in diverse fields owing to their high strength-to-weight ratio, low cost, and ease of fabrication [1-3]. Substituting the base aluminum alloys with particulate composites has the advantage of improving the mechanical strength parameters without seriously disturbing the thermal and electrical conductivities and other properties 
[4-7]. The common reinforcement particles used in $\mathrm{AMMCs}$ are graphite, $\mathrm{SiO}_{2}, \mathrm{SiC}, \mathrm{Al}_{2} \mathrm{O}_{3}$ and $\mathrm{B}_{4} \mathrm{C}$ used in small percentages of about 2 to 8\% [8-12]. Some researchers have used hybrid reinforcement, i.e., using two types of particulates [13-14], while some others have employed dual or treble sizes of same particulate [15-16]. The automaker Honda uses a hybrid AMMC for some of its engine blocks [17]. Of the reinforcement particulates available, $\mathrm{B}_{4} \mathrm{C}$ is perhaps the hardest. Hence an $\mathrm{AMMC}$ with $\mathrm{B}_{4} \mathrm{C}$ particles may be expected to have higher strengths than other AMMCs. The work presented here, which is part of a larger comprehensive study, is based on aluminum alloy particulate composites with $\mathrm{B}_{4} \mathrm{C}$ particles. In this study, two sizes of $\mathrm{B}_{4} \mathrm{C}$ particles $(44 \mu \mathrm{m}$, and $105 \mu \mathrm{m})$ in different ratios were employed to obtain three AMMCs in the as-cast condition. These were evaluated for their microstructural features and mechanical properties using standard testing procedures.

\section{MATERIALS AND METHODS}

he cast aluminum alloys A 356 was selected for the study. The chemical composition of the alloy as tested and as required by standard is given in Tab. 1. Two sizes of $\mathrm{B}_{4} \mathrm{C}$ powder, one fine and the other coarse, viz., $44 \mu \mathrm{m}$ and $105 \mu \mathrm{m}$ were procured from reputed suppliers. The chemical assay of $\mathrm{B}_{4} \mathrm{C}$ powders is given in Tab. 2. The physical properties of aluminum, which is the major component of $\mathrm{A} 356$ alloy, and $\mathrm{B}_{4} \mathrm{C}$ are compared in Tab. 3.

\begin{tabular}{ccccccccccc}
\hline Elements & $\mathrm{Si}$ & $\mathrm{Mg}$ & $\mathrm{Fe}$ & $\mathrm{Cu}$ & $\mathrm{Mn}$ & $\mathrm{Ni}$ & Zinc & others & $\mathrm{Al}$ \\
Weight $\%$ & 7.18 & 0.34 & 0.13 & 0.05 & 0.027 & 0.03 & 0.01 & 0.15 & Balance \\
\hline
\end{tabular}

Table 1: Chemical Composition analysis of A356.

\begin{tabular}{cc}
\hline Element / component & Weight $\%$ \\
$\mathrm{Fe}$ & 0.2 \\
$\mathrm{Si}$ & 0.1 \\
$\mathrm{~B}_{2} \mathrm{O}_{3}$ & 0.5 \\
$\mathrm{~B}_{4} \mathrm{C}$ & Balance \\
$\mathrm{B}$ & 79 \\
$\mathrm{C}$ & 20 \\
\hline
\end{tabular}

Table 2: Chemical Composition Assay of $\mathrm{B}_{4} \mathrm{C}$ Particles.

\begin{tabular}{ccc}
\hline Property & $\mathrm{A} 356$ & $\mathrm{~B}_{4} \mathrm{C}$ \\
Melting Point, ${ }^{\circ} \mathrm{C}$ & 750 & 2363 \\
Boiling Point, ${ }^{\circ} \mathrm{C}$ & 2425 & 3500 \\
Density, $\mathrm{kg} / \mathrm{m}^{3}$ & 2670 & 2420 \\
Crystal Structure & FCC & Rhombohedral \\
Hardness, VPN & 65.8 & $94-97$ \\
Tensile Strength, MPa & 143 & 350 \\
\hline
\end{tabular}

Table 3: Comparison of physical properties of A356 and $\mathrm{B}_{4} \mathrm{C}$ Particles. 
Preparation of materials

The AMMCs were prepared by the well-established stir casting method. Pieces of A 356 alloy cut from ingots were placed in a graphite crucible and melted in an electric resistance furnace (schematic diagram of stir casting is shown in Fig.1). The melt was degassed using hexachloromethane tablet, and held at above $800^{\circ} \mathrm{C}$, and stirring started. When a nice vortex was formed, pre-weighed quantities of $\mathrm{B}_{4} \mathrm{C}$ powders were introduced, and stirring continued. After about three minutes, the melt was skimmed and the liquid metal poured into preheated finger molds. The three compositions of the AMMC, viz., $2 \% \mathrm{~B}_{4} \mathrm{C}\left(44 \mu\right.$ size and $105 \mu$ size in 1:1 ratio), $4 \% \mathrm{~B}_{4} \mathrm{C}$ (3:1 ratio), and $6 \% \mathrm{~B}_{4} \mathrm{C}(1: 3$ ratio), as shown in Tab. 4 , were prepared as detailed above. From these cast fingers, test specimens for hardness, microstructure and tensile tests were machined as per ASTM standards

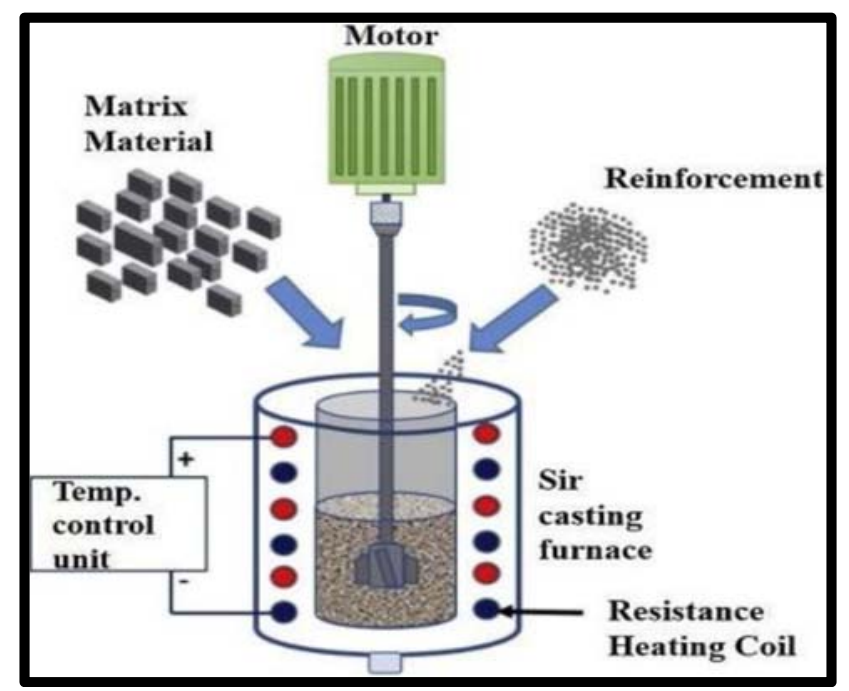

Figure 1: schematic diagram of stir equipment.

$\begin{array}{cccc}\text { Sl no } & \text { A356 wt } \% & \mathrm{~B}_{4} \mathrm{C} w \mathrm{wt} \% & \begin{array}{c}\text { Ratio of fine and } \\ \text { coarse } \mathrm{B}_{4} \mathrm{C} \\ \text { Particle }\end{array} \\ 1 & 100 & - & - \\ 2 & 98 & 2 & \text { 1Fine:1Coarse } \\ 3 & 96 & 4 & \text { 3Fine:1Coarse } \\ 4 & 94 & 6 & \text { 1Fine:3Coarse }\end{array}$

Table 4: Material composition with different ratios of fine and coarse size $\mathrm{B}_{4} \mathrm{C}$ particle.

\section{Microstructural examination}

The test specimens were polished to 6-0 smoothness and etched with Keller's Reagent. An Optical Microscope (Model NIKON LV-150, Fig.2) was used for the purpose.

\section{Hardness tests}

Hardness tests were performed on specimens polished to 5-0 smoothness with a Vickers Micro Hardness Tester (Model VHM-102, Fig. 3(a)). The applied load was $100 \mathrm{~g}$ for $10 \mathrm{~s}$. Fig. 3(b) shows the schematic of hardness specimen. 


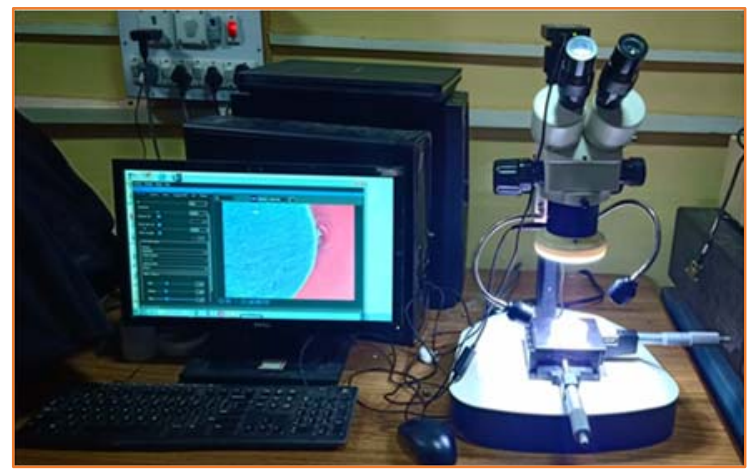

Figure 2: Optical microscope.
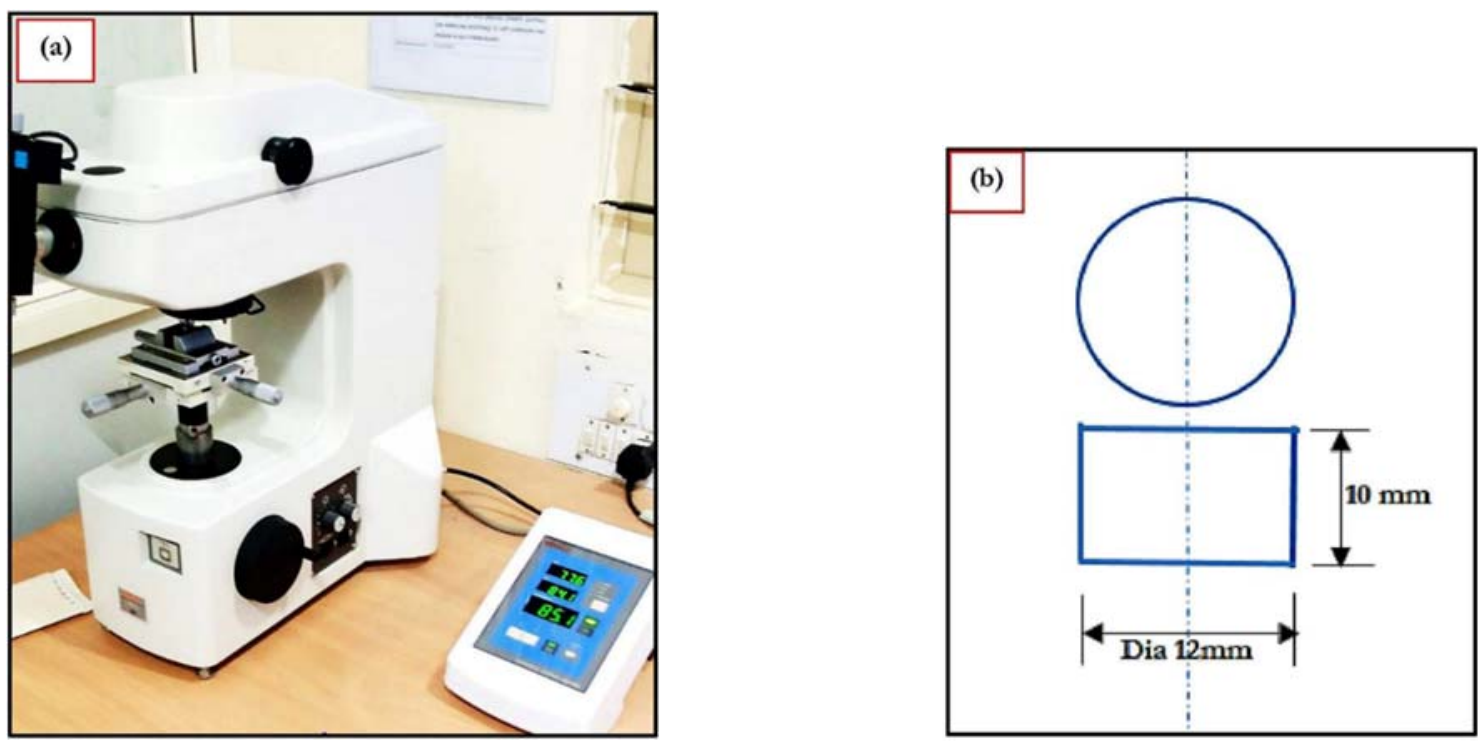

Figure 3: (a) MITUTOYO Vickers hardness Testing Machine (b) schematic of hardness specimen

Tensile tests

The tensile test specimens were of $6.35 \mathrm{~mm}$ diameter and gauge length of $26 \mathrm{~mm}$, conforming to ASTM E8 Standard. The tensile tests were accomplished using a Hounsfield-type testing machine (Model TUE-C-400, Fig. 4(a)) at a strain rate of 0.2 $\mathrm{mm} / \mathrm{s}$, at room temperature. Fig 4(b) shows Schematic of Tensile specimen.
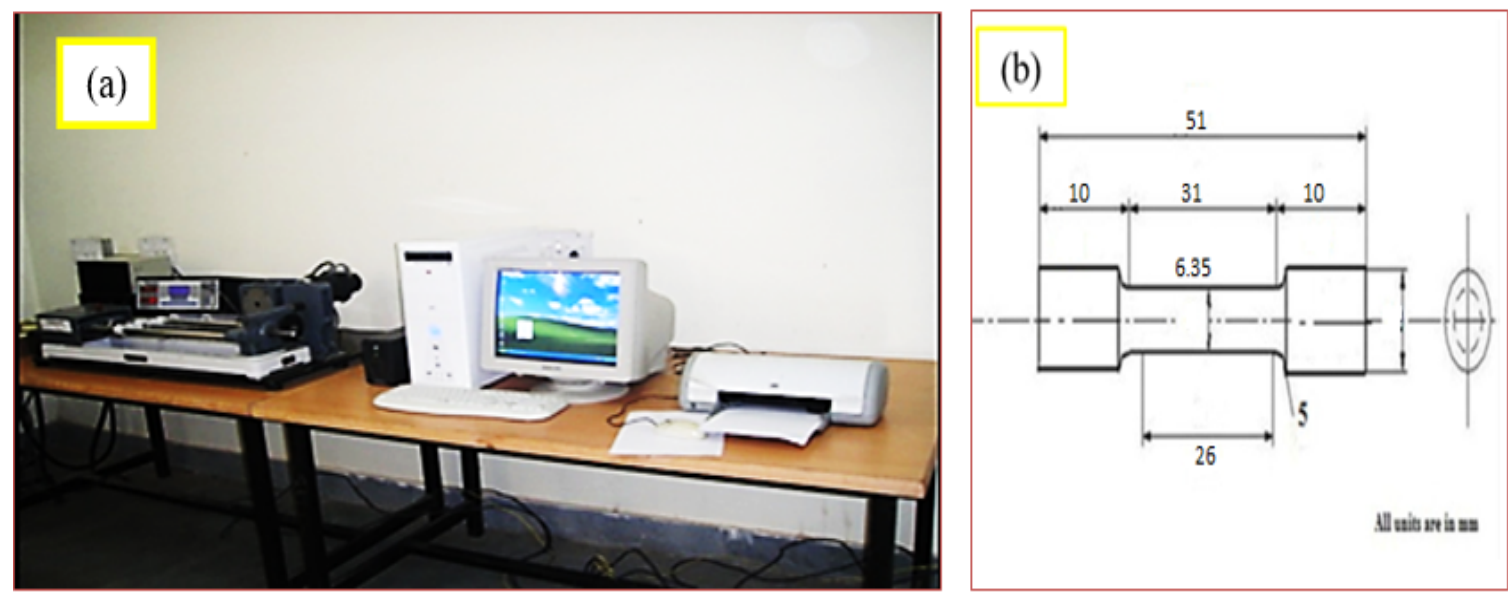

Figure 4: Tensile testing (a) tensile testing machine (b) Schematic of Tensile specimen. 


\section{RESULTS AND DISCUSSIONS}

\section{Microstructure}

7 he photomicrographs of the as-cast structures of base A 356 alloy, and $\mathrm{AMMCs}$ with A 356 and $2 \% \mathrm{~B}_{4} \mathrm{C}, 4 \% \mathrm{~B}_{4} \mathrm{C}$, and $6 \% \mathrm{~B}_{4} \mathrm{C}$ respectively is shown in the Fig.5.(a to d), From Fig. 5(a), it is seen that the cast structure of the base A 356 alloy is dendritic or semi-dendritic. The Al-Si eutectic phase forms the dendritic structure with in a matrix of primary $\alpha$ - $\mathrm{Al}$ phase. Figs. 5 (b), (c)and (d), being the microstructures of cast $2 \% \mathrm{~B}_{4} \mathrm{C}, 4 \% \mathrm{~B}_{4} \mathrm{C}$, and $6 \% \mathrm{~B}_{4} \mathrm{C}$ respectively, indicate that the structures of all three cat composites are similar. There is nearly uniform distribution of $\mathrm{B}_{4} \mathrm{C}$ particles in all three composite castings. This is true for the fine $\mathrm{B}_{4} \mathrm{C}$ particles, as well as for the coarse $\mathrm{B}_{4} \mathrm{C}$ particles. The microstructural examination reveals simple primary $\alpha$-Al phase as matrix in which there are dendrites of the intermetallic Al-Si phase. In the composites, there is distribution of the $\mathrm{B}_{4} \mathrm{C}$ particles, which are mostly spheroidal in shape. [18].
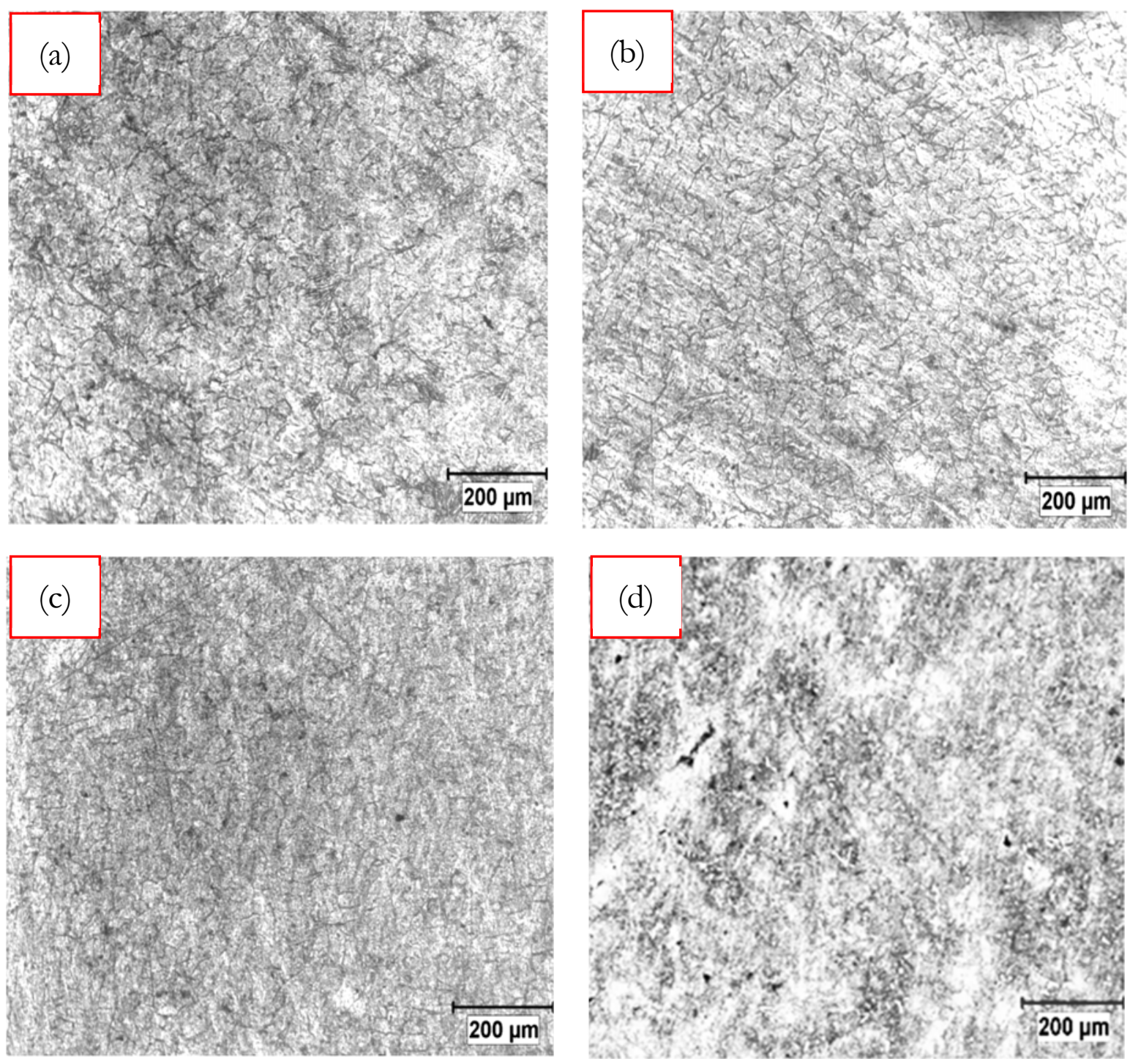

Figure 5: photomicrographs of (a) base A 356 alloy, (b) A356+2\% $\mathrm{B}_{4} \mathrm{C}$, (c) $\mathrm{A} 356+4 \% \mathrm{~B}_{4} \mathrm{C}$, (d) $\mathrm{A} 356+6 \% \mathrm{~B}_{4} \mathrm{C}$,

Energy dispersive spectroscopy (EDS) spectrum

Energy dispersive spectroscopy (EDS) permits researcher to identify what those particular elements are and also their comparative proportions in the selected area. This technique is one of the influential and convenient type of elemental 
investigation. The graphical depiction of EDS analysis of $\mathrm{A} 356$ aluminum alloy, $\mathrm{A} 356+2 \% \mathrm{~B}_{4} \mathrm{C}, \mathrm{A} 356+4 \% \mathrm{~B} 4 \mathrm{C}$ and A $356+6 \% \mathrm{~B}_{4} \mathrm{C}$ composites is shown in Figs. 6(a to d) respectively.

From Fig. 6 (a) is the EDS spectrograph of A356 aluminum alloy. The spectrum confirms the existence of aluminum as the uppermost element followed by silicon and magnesium alloys. From Fig. 6(b to d) is the EDS spectrograph of A356 and $\mathrm{B}_{4} \mathrm{C}$ composites spectrum which evidence the existence of boron (B), carbide (C), in the carbon form.

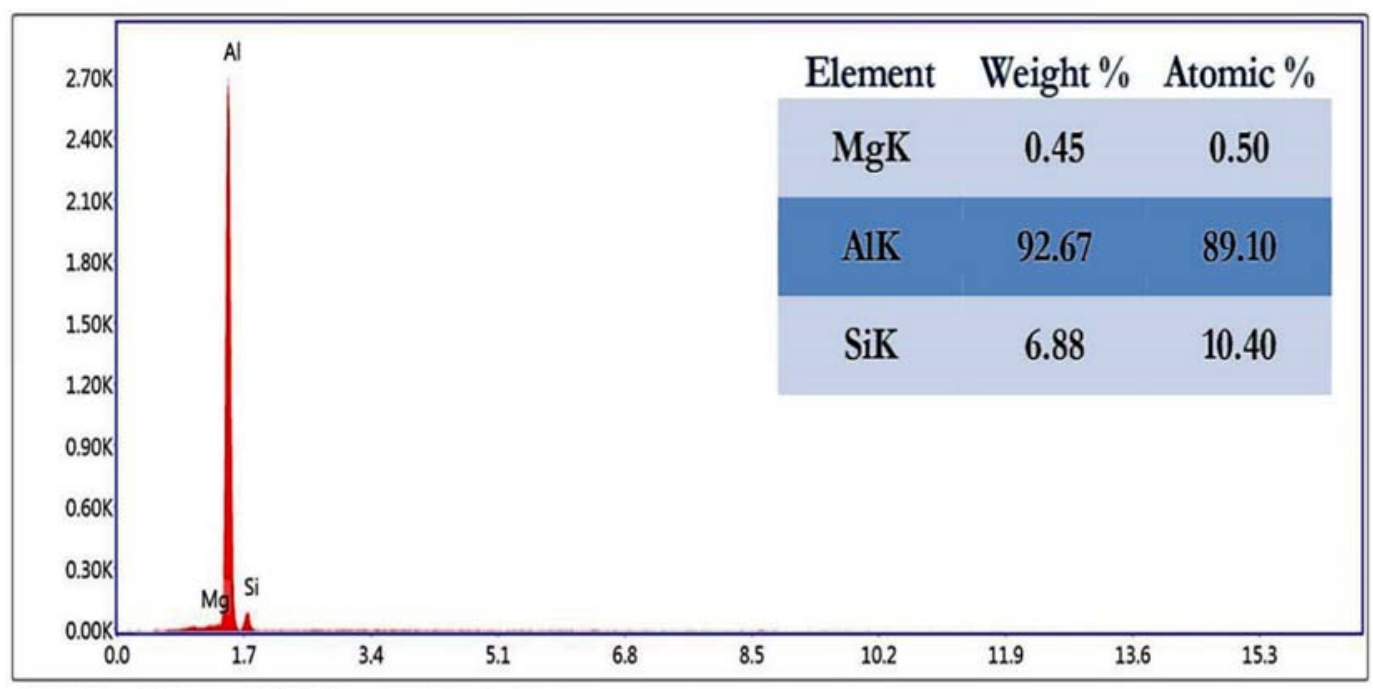

Lsec: $30.0 \quad 0$ Cnts $\quad 0.000 \mathrm{keV} \quad$ Det: Octane Pro Det

Figure 6: (a) shows the EDS spectrum of A356 alloy

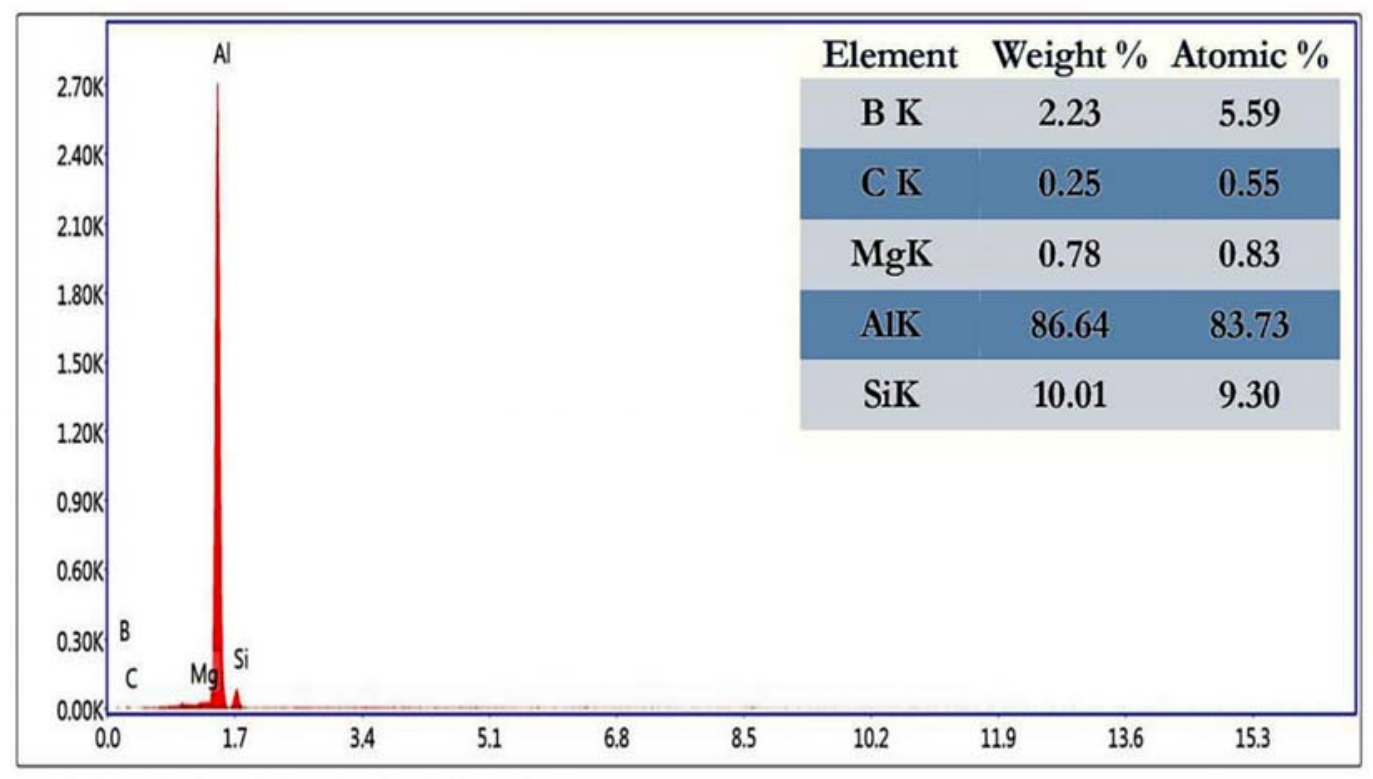

Lsec: $30.0 \quad 2$ Cnts $4.335 \mathrm{keV} \quad$ Det: Octane Pro Det

Figure 6: (b) shows the EDS spectrum of $\mathrm{A} 356+2 \% \mathrm{~B}_{4} \mathrm{C}$ Composite. 


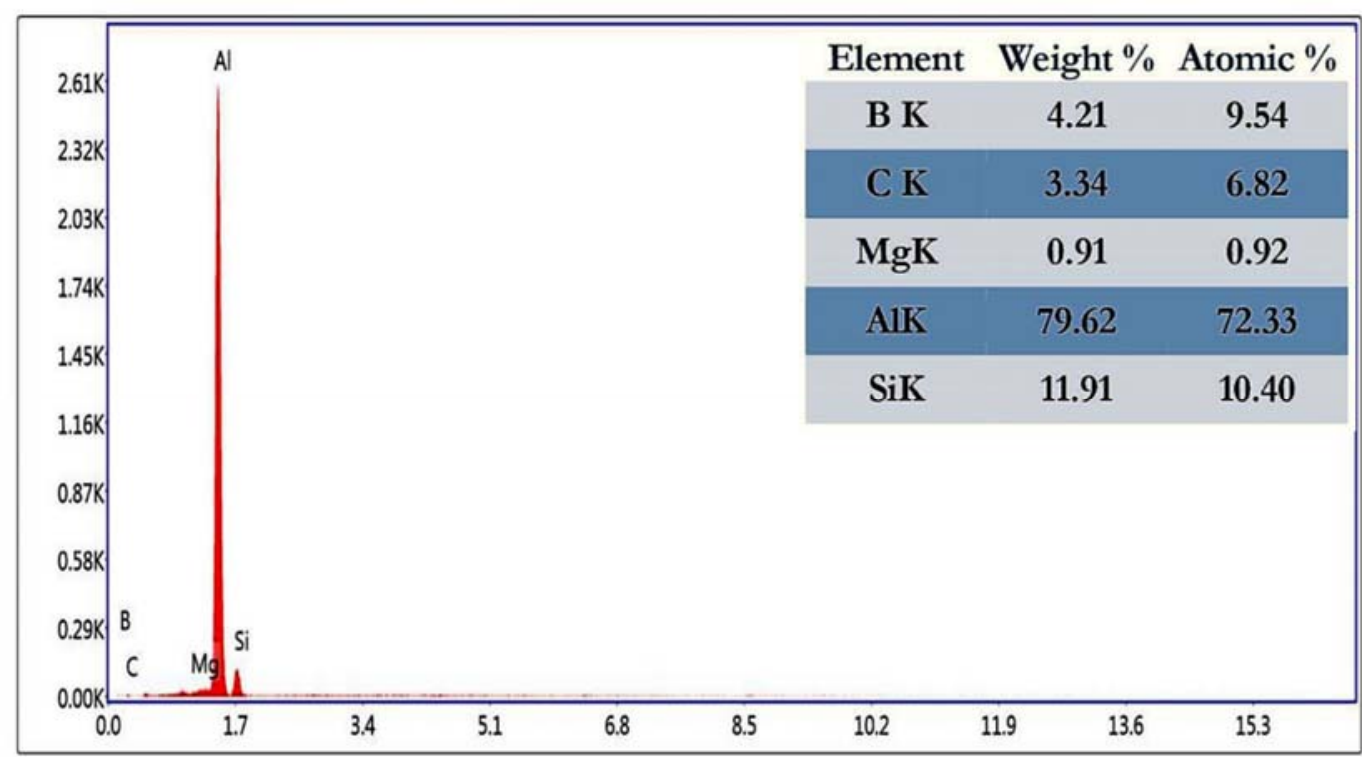

Lsec: $30.0 \quad 2$ Cnts $\quad 0.155 \mathrm{keV} \quad$ Det: Octane Pro Det

Figure 6: (c) shows the EDS spectrum of $\mathrm{A} 356+4 \% \mathrm{~B}_{4} \mathrm{C}$ Composite.

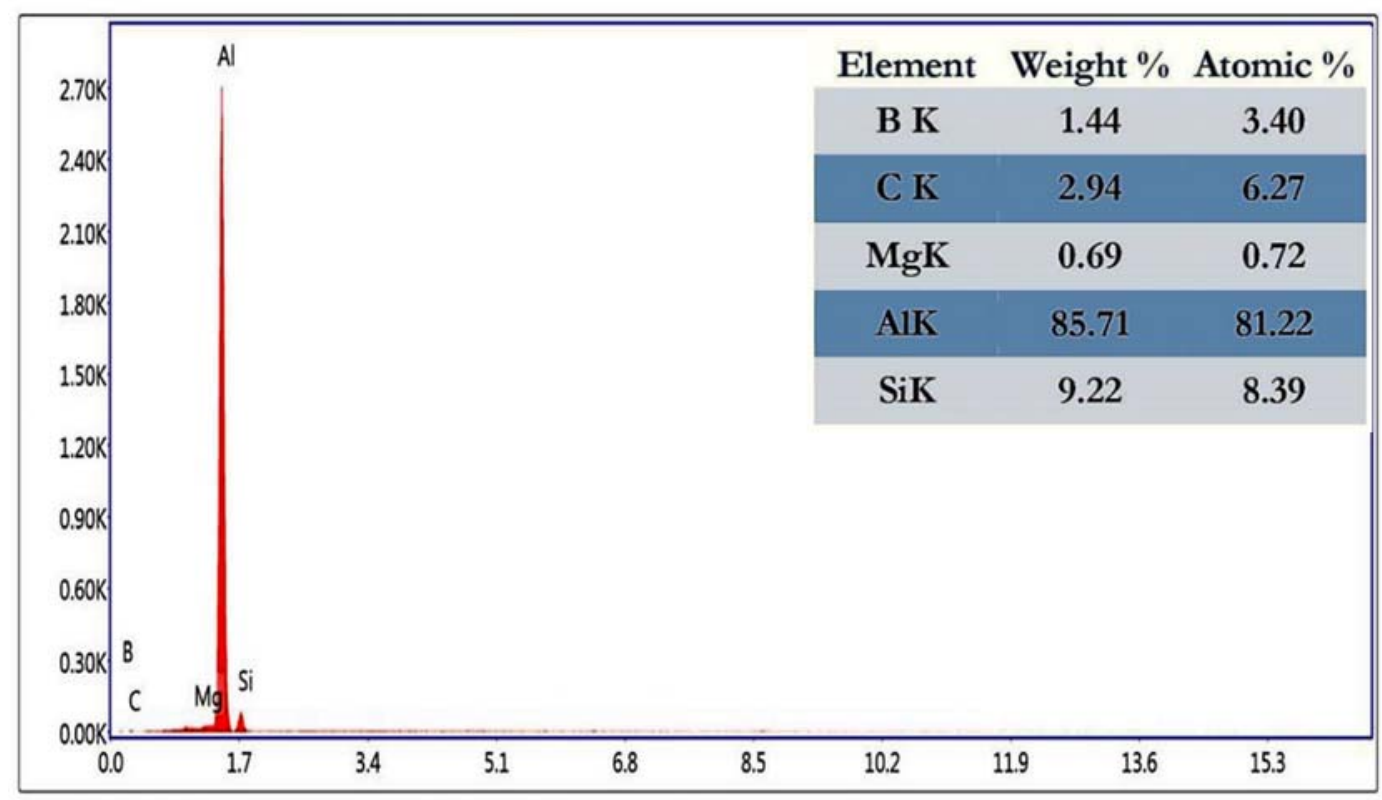

Lsec: $30.0 \quad 2$ Cnts $4.335 \mathrm{keV} \quad$ Det: Octane Pro Det

Figure 6: (d) shows the EDS spectrum of $\mathrm{A} 356+6 \% \mathrm{~B}_{4} \mathrm{C}$ Composite.

\section{Hardness}

Fig. 7 is a bar graph of the hardness values of the A 356 alloy and the three composites, hardness being measured in VHN. It is seen from Fig. 7 that while the composites seem to have higher hardness than the base A 356 alloy, the increase in hardness is being $6 \%, 3.4 \%$ and $14.14 \%$ respectively for the composites with $2 \%, 4 \%$ and $6 \% \mathrm{~B}_{4} \mathrm{C}$.

Among the Dual size particle composites, the composite with $6 \% \mathrm{~B}_{4} \mathrm{C}$ of the ratio 1 fine and 3 coarse size particles shows marginally higher hardness. This may be due to the higher ratio of coarse size $\mathrm{B}_{4} \mathrm{C}$ particle. The higher amount of coarse 
particle in AMMC shields the finer particles, additionally coarse particles helps to carry a extra portion of the applied load in comparison with the finer size particles [19].

The composite with $4 \% \mathrm{~B}_{4} \mathrm{C}$ of the ratio 3 fine: 1 coarse particle particles shows slightly lower hardness. This may be due to the higher amount of fine size $\mathrm{B}_{4} \mathrm{C}$ particle. The higher amount of the fine size is more prone to the particle clustering hence the dispersion of fine size particle is very difficult [20-21].

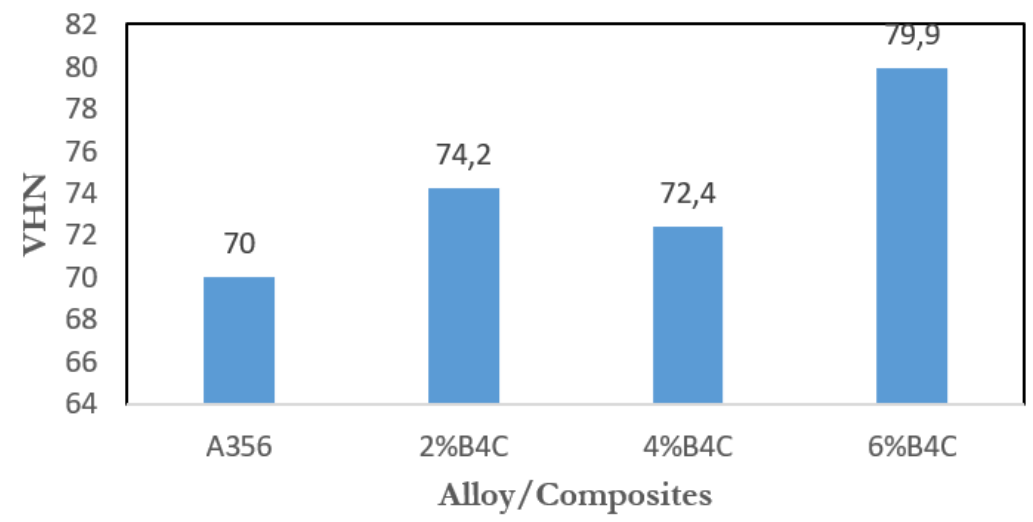

Figure 7: Hardness Values of As-Cast A356 Alloy and Composites.

\section{Tensile strength}

Fig. 8 plots the UTS of the base alloy and three composites in their as-cast condition. While there is no significant increase in UTS by adding $2 \%$ or $4 \% \mathrm{~B}_{4} \mathrm{C}$ (increase in UTS by $3.8 \%$ and $7.5 \%$ respectively), there is a significant increase achieved by adding $6 \% \mathrm{~B}_{4} \mathrm{C}$ with the ratio of 1 fine and 3 coarse size. (an increase of $38.8 \%$ ). The $\mathrm{B}_{4} \mathrm{C}$ ceramic particle acts as a barrier against the plastic deformation in the A356 matrix material to counter the tensile load.

The composite with $6 \% \mathrm{~B}_{4} \mathrm{C}$ of the ratio 1 fine:3 coarse size particle exhibits higher UTS this may be due to the increase in the $\mathrm{wt}^{\%} \%$ of $\mathrm{B}_{4} \mathrm{C}$ reinforced particle [22-23]. and also a significant increase due to the higher ratio of coarse size $\mathrm{B}_{4} \mathrm{C}$ particle in the composites. Higher ratio of coarse size $\mathrm{B}_{4} \mathrm{C}$ particle acts as an effective stress carrier between reinforcement and matrix material. [24]

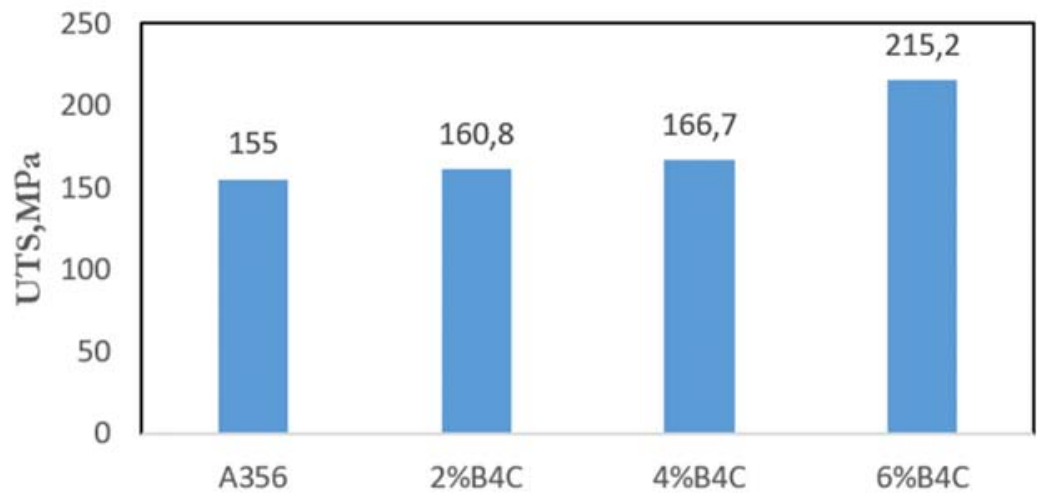

Alloy/Composites

Figure 8: UTS of As-Cast A 356 Alloy and Composites

\section{Ductility (\% of Elongation)}

Fig. 9 is a plot showing the ductility (represented by \% Elongation) of the Base A356 alloy and the three composites. It is evident from Fig. 7 that there is a significant loss in ductility in composites as compared with the A356 alloy. The loss in ductility, as calculated by the reduction in \% Elongation is found to be $24.2 \%, 27.1 \%$, and $28.6 \%$ respectively for the $2 \%$, $4 \%$, and $6 \% \mathrm{~B}_{4} \mathrm{C}$ composites. It is further evident that the $\%$ Elongation decreases as the $\mathrm{B}_{4} \mathrm{C}$ particulate quantity increases [25] irrespective of the sizes of the $\mathrm{B}_{4} \mathrm{C}$ particle. (though initially there is a drastic drop in \% Elongation from the Base A 356 alloy and $2 \% \mathrm{~B}_{4} \mathrm{C}$.this is due to the presence of needles like of silicon in the $\alpha$-Al Matrix (silicon is the second highest constituent of A356 alloy) is responsible for the reduction in ductility [26-27]. 


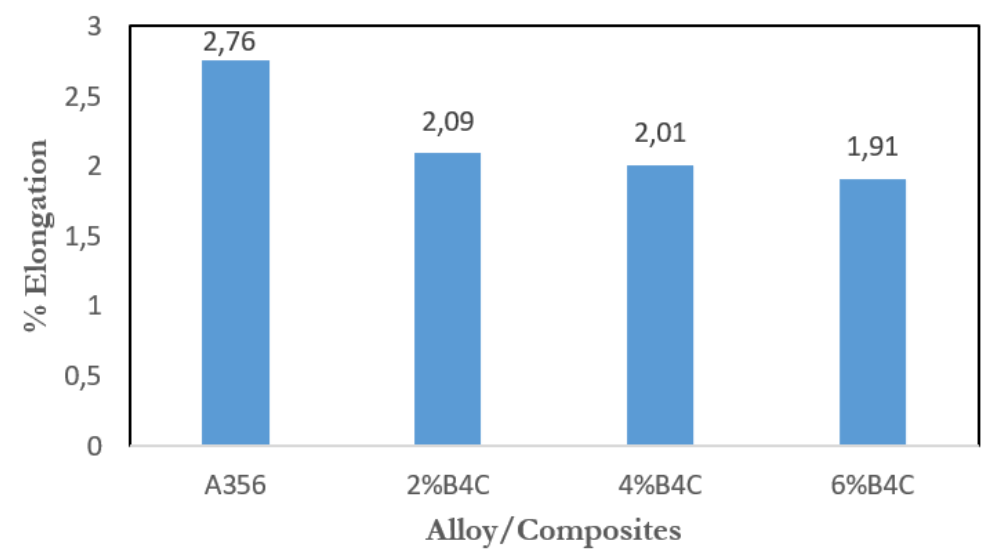

Figure 9: Bar Chart of \% Elongation for As-Cast A 356 Alloy and Composites

Tensile Fracture analysis

Fig.10 shows the SEM images of A356alloy, $2 \mathrm{wt} \%, 4 \mathrm{wt} \%$ and $6 \mathrm{wt} \%$ of $\mathrm{B}_{4} \mathrm{C}$ composites after the tensile test. The A356 alloy shows an inter crystalline fracture, fig 10(a) this is due to the existence of dendritic shrinkage porosity. The reason is that the crack nucleation at the inter-dendritic region and propagation along these dendrites is the primary mechanism for failure of A356 alloys. all the A356 composites exhibited brittle failure along with quasi-cleavage feature, as shown in Fig. 10 ( $\mathrm{b}$ to d). the micro cracks and quasi-cleavage feature is common feature of materials with lower elongation. This may be due to the detachment of coarse size $\mathrm{B}_{4} \mathrm{C}$ Particle. A small dimple was also absorbed on fracture area of the composite, fracture of coarse size $\mathrm{B}_{4} \mathrm{C}$ causes pullout due to the decrease in ductility as compared to the $\mathrm{A} 356$ alloy. From all this observation it is considered that as the load increase $\mathrm{B}_{4} \mathrm{C}$ particle of both size, breaks instead of debonding hence the nature of fracture in the composites is brittle \& quasi cleavage type. [28-29].
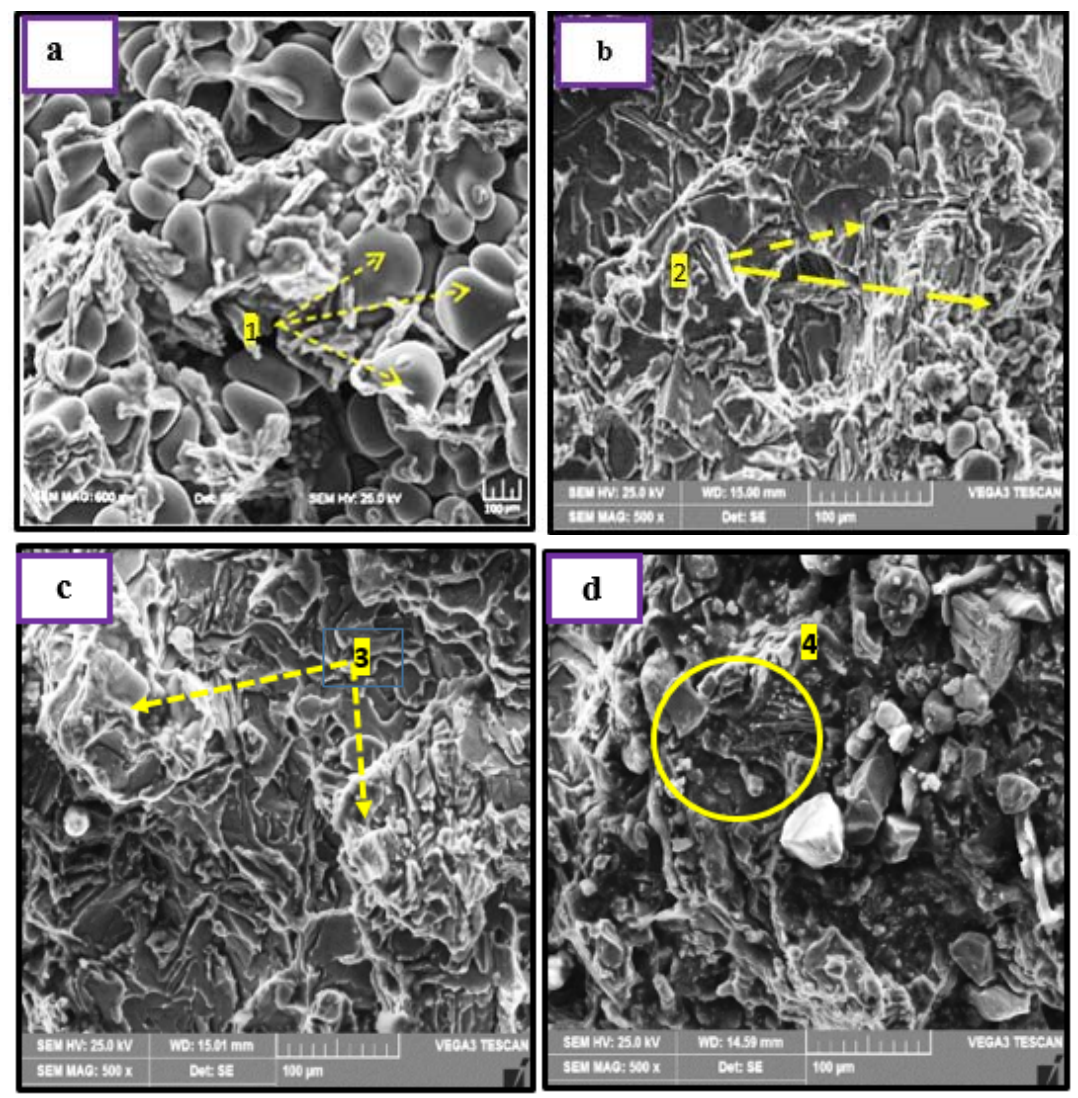

Figure 10: Fractographs of (a) base A 356 alloy, (b) $\mathrm{A} 356+2 \% \mathrm{~B}_{4} \mathrm{C}$, (c) $\mathrm{A} 356+4 \% \mathrm{~B}_{4} \mathrm{C}$, (d) $\mathrm{A} 356+6 \% \mathrm{~B}_{4} \mathrm{C}$, In the figure, 1 represents $\alpha$-Al grains, 2 represents micro cracks and voids 3 represents small dimples 4 represents shrinkage porosity. 


\section{ConClusions}

he following conclusions / inferences could be drawn from the present study on as-cast A 356 alloy and its composites with $2 \%, 4 \%$ and $6 \% \mathrm{~B}_{4} \mathrm{C}$ particulates with dual size.

1. Stir casting can be used to successfully prepare A $356-\mathrm{B}_{4} \mathrm{C}$ composites up to $6 \% \mathrm{~B}_{4} \mathrm{C}$ particulates without any problem. Uniform distribution of $\mathrm{B}_{4} \mathrm{C}$ particles, fine or coarse, can be achieved.

2. The microstructural examination reveals simple primary $\alpha-\mathrm{Al}$ phase as matrix in which there are dendrites of the intermetallic $\mathrm{Al}-\mathrm{Si}$ phase. In the composites material, there is distribution of the $\mathrm{B}_{4} \mathrm{C}$ particles, which are mostly spheroidal in shape.

3. EDS spectrograph of $\mathrm{A} 356$ and $\mathrm{B}_{4} \mathrm{C}$ composites spectrum which evidence the presence of boron (B), carbide (C), in the carbon form.

4. While there is an increase in hardness values by addition of $6 \mathrm{wt} \%$ of $\mathrm{B}_{4} \mathrm{C}$ at the ratio of 1 fine and 3 coarse size, (increased by $14.14 \%$ ) this is due to the higher ratio of coarse particle in composites shields the finer sized particles, but there is a decrease in hardness values by addition of $4 \mathrm{wt} \%$ of at the ratio of 3 fine and 1 coarse size $\mathrm{B} 4 \mathrm{C}$ particle, (decreased by $3.4 \%$ ) this is due to clustering of higher amount of fine size particle.

5. There is significant increase in UTS (nearly an increase of $40 \%$ ). In the composite of $6 w t^{0} \%$ of $\mathrm{B}_{4} \mathrm{C}$ with a ratio of 1 fine and 3 coarse size $\mathrm{B}_{4} \mathrm{C}$ particle when compared to the other two composites, this is due to the Higher ratio of coarse size $\mathrm{B}_{4} \mathrm{C}$ particle acts as an effective stress carrier between reinforcement and matrix material.

6. There is a decrease in ductility in composites, which may be expected. However, with increased amount of $\mathrm{B}_{4} \mathrm{C}$ particulates $(2 \mathrm{wt} \%, 4 \mathrm{wt} \%$ \& $6 \mathrm{wt} \%)$, ductility loss is minimal. It is evidence that the $\%$ of elongation decreases with the increase in $\mathrm{wt} \%$ of $\mathrm{B}_{4} \mathrm{C}$ particle in the composites irrespective of the sizes of the $\mathrm{B}_{4} \mathrm{C}$ particle.

7. The fractographic studies reveals that as the load increase $\mathrm{B}_{4} \mathrm{C}$ particle of both size, breaks instead of debonding hence the nature of fracture in the composites is brittle \& quasi cleavage type.

\section{REFERENCES}

[1] Rama koteswara Rao, V., Rangaraya Chowdary, J. and Balaji, A. (2016). A Review on Properties of Aluminium Based Metal Matrix Composites via Stir Casting, International Journal of Scientific \& Engineering Research, 7(2), pp. 742-749. ISSN 2229-5518,

[2] Dwivedi, S. P., Sharma, S., Raghavendra kumara Mishra (2014). A356 Aluminium Alloy and applications A Review Advanced Materials Manufacturing \& Characterization, Advanced materials manufacturing \& characterization, 4(2), pp. 81-86. DOI:10.11127/ijammc.2014.08.01.

[3] Singh, R. and Rai, R. N. (2018). Characterization of B4C-composite reinforced minimum alloy composites, AIP Conference Proceedings, pp. 020073-11. DOI:10.1063/1.5029649.

[4] Frank Czerwinski. (2020). Review Thermal Stability of Aluminum Alloys, Canmet materials, Natural Resources Canada Materials, 13(15), pp. 1-49. DOI:10.3390/ma13153441.

[5] Summers, P.T. Chen, Y. Rippe, C.M and Ben Allen. (2015). Overview of aluminum alloy mechanical properties during and after fires, Fire Science Reviews, DOI 10.1186/s40038-015-0007-5.

[6] Omotoyinbo, J.A. Oladele, I.O. and Shokoya, W. (2014). Effect of the Degree of Plastic Deformation on the Electrical Resistance and Thermal Conductivity of Al-Mg-Si Alloy Leonardo Electronic, Journal of Practices and Technologies, 13(24), pp. 37-50.

[7] Mamala, A. and Sciezor, W. (2014). Evaluation of the effect of selected alloying elements on the mechanical and electrical aluminium properties, archives of metallurgy and material, 59(1), pp. 413-417. DOI: 10.2478/amm-2014-0069.

[8] Sridhar Raja, K. and Bupesh Raja, S. (2013). Production and Characteristic of Boron Carbide Reinforced Aluminum A356 Composites, International Journal on Design and Manufacturing Technology, 7(2), pp. 29-32.

DOI: /10.18000/ijodam.70131.

[9] Vencl, A., Bobic, I. and Arostegui, S. (2010). Structural Mechanical and tribological properties of A356 aluminium alloy reinforced with $\mathrm{SiC}, \mathrm{Al}_{2} \mathrm{O}_{3}$ Particles, Journal of Alloys and Compounds, 506(2), pp. 631-639.

DOI: $10.1016 /$ j.jallcom.2010.07.028.

[10] Vanarotti, M., Shrishail, P., Sridhar, B.R., Venkateswarlu, K. and Kori, S.A., (2014). Surface Modification of Sic Reinforcements \& Reinforcements \& Its Effects on Mechanical Properties of Aluminum Based MMC, Applied Mechanics and Materials, 446(447), pp. 93-97. DOI: 10.4028/www.scientific.net/AMM.446-447.93. 
[11] Hu, Q., Zhao, H. and Li, F. (2016). Effects of Manufacturing Processes on Microstructure and Properties of Al/A356B4C Composites, Materials and Manufacturing Processes, 31(10), pp. 1292-1300.

DOI: $10.1080 / 10426914.2016 .1151049$.

[12] Nirala. A., Soren, S., Kumar, N.and Kaushal, D.R. (2019). A comprehensive review on mechanical properties of AlB4C stir casting fabricated, composite Materials Today proceedings, 21(3), pp. 1432-1435. DOI: $10.1016 /$ j.matpr.2019.09.172.

[13] Sukesha, V., Ranjan, R., Nagesh, G. and Sekar, K. (2014). Fabrication and study on mechanical and tribological properties of $\mathrm{NanoAl}_{2} \mathrm{O}_{3}$ and Micro $\mathrm{B}_{4} \mathrm{C}$ Particles reinforced A356 Hybrid composites, (AIMTDR).

[14] Rajmohan, T., Palanikumar, K. and Ranganathan, S. (2013). Evaluation of mechanical and wear properties of hybrid aluminum matrix composites, Transactions of Nonferrous Metals Society of China, 23(9), pp. 2509-2517. DOI: $10.1016 /$ S1003-6326(13)62762-4.

[15] Nanda Kumar, N. and Muthukumaran, N. (2019). Experimental Investigation on Microstructural and Wear Behaviour of Dual Reinforced Particles (DRP) Aluminium Alloy Composites, Advanced Materials Research, 1159(1), pp. $42-53$. DOI: $10.4028 / w w w . s c i e n t i f i c . n e t / A M R .1159 .42$.

[16] Bindumadhavan, P.N., Keng Wah, H. and Prabhakar, O. (2001). Dual particle size (DPS) composites: effect on wear and mechanical properties of particulate metal matrix composites, wear, 248(1), pp.112-120. DOI: $10.1016 /$ S0043-1648(00)00546-9.

[17] Stojanovic, B. and Ivanovic, L. (2015). Application of aluminium hybrid composites in automotive industry, Research gate, Article in Tehnicki Vjesnik, 22(1), pp. 247-251. DOI: 10.17559/TV-20130905094303.

[18] Islam, S. K., Das, T.,Das. P. (2015). Deformation behaviour of Rheocast A356 Al alloy at microlevel considering approximated RVEs, Metals and Materials International, 21(2), pp.311-323. DOI: $10.1007 / \mathrm{s} 12540-015-4234$

[19] Kumar, S., Sharma, V., Panwar, R.S. (2012). Wear Behavior of Dual Particle Size (DPS) Zircon Sand Reinforced Aluminum alloy. Tribol Lett, 47(3), pp.231-251. DOI: 10.1007/s11249-012-9983.

[20] Montoya-Davilaa, M., Pech-Canul, M.A, Pech-Canul, M.I. (2007). Effect of bimodal and tri-size distribution on thesuperficial hardness of $\mathrm{Al} / \mathrm{SiCp}$ composites prepared by pressure less infiltration. Powder Technology, 176(2), pp. 66-71. DOI: 10.1016/j.powtec.2007.02.008.

[21] Lakshmikanthan, A., Bontha, S., Krishna, M., Praveennath, G. and Koppad Ramprabhu., T. (2019). Microstructure, mechanical and wear properties of the A357 composites reinforced with dual sized SiC particles, Journal of Alloys and Compounds, 786(8), pp. 570-580. DOI: 10.1016/j.jallcom.2019.01.382.

[22] Beigi Khosroshahi, N., Taherzadeh Mousavian, R., Azari Khorsoshahi, R. and Brabazon, D. (2015). Mechanical properties of rolled A356 based composites reinforced by $\mathrm{Cu}$ coated bimodal ceramic particles, Material \&Design, 83(5), pp.678-688. DOI: 10.1016/j.matdes.2015.06.027.

[23] Venkat Kishore, N. and Venkata Rao, K. (2016). Mechanical Properties in MMC of Aluminum Alloy (A356/LM25) Matrix and Boron Carbide (B4C) Reinforcement, International Journal of Engineering Research \& Technology (IJERT), 5(2), pp.683-689.

[24] Fu, S.-Y., Feng, X.-Q., Lauke, B. and Mai, Y. W. (2008). Effects of particle size, particle/matrix interface adhesion and particle loading on mechanical properties of particulate, polymer composites Composites Part B, 39(6), pp.933-961. DOI: $10.1016 /$ j. compositesb.2008.01.002.

[25] Kanta Das, D., Chandra Mishra, P., Singh, S. and Kumar Thakur, R. (2014). Properties of ceramic-Reinforced aluminium matrix composites - a review, International Journal of Mechanical and Materials Engineering, 9(12), pp.116. DOI:10.1186/s40712-014-0012-9.

[26] Kori, S.A. and Chandrashekharaiah, T.M. (2007). Studies on the dry sliding wear behavior of hypoeutectic and eutectic Al-SiC alloys, wear, 263(1), pp. 745-755. DOI: 10.1016/j.wear.2006,11,026.

[27] Karabulut, S., Karakoc, H. and Citak, R. (2016). Influence of B4C particle reinforcement on mechanical and machining properties of Al6061/B4C composites, Composites Part B, 101(15), pp. 87-98.

DOI: $10.1016 /$ j.compositesb.2016.07.006.

[28] Chen, Z., Hao, X., Wang, Y.and Zhao, K. (2014). In-situ observation of tensile fracture in A357 casting alloys, J. Mater. Sci.Technol, 30(6), pp. 139-145. DOI: 10.1016/j.jmst.2013.04.014.

[29] Jiang, W., Fan, Z., Dai, Y. and Li, C. (2014). Effects of rare earth elements addition on microstructures, tensile properties and fractography of A357 alloy, Mater. Sci.Eng, A 597(12), pp.237-244. DOI: 10.1016/j.msea.2014.01.009. 